\title{
Correspondence
}

\section{Virchow and Apoptosis}

\section{To the Editor-in-Chief:}

Apoptosis is a type of cell death that has specific morphological, biochemical, and regulatory characteristics, somehow different from necrosis. ${ }^{1}$ It was described in our time by the Australian pathologist John $\mathrm{Kerr}^{2,3}$ and given its present name by Kerr et al in 1972. ${ }^{4}$ It is interesting that this type of cell death was also described by Glucksman in 1951 as present in normal embryological development. $^{5}$

We found recently that the famous German pathologist and biologist Rudolf Virchow (1821-1902) described apoptosis in a lecture given in $1858 .{ }^{6}$ In it, he described two types of cell death, necrobiosis versus necrosis. The former is "always here to deal with a gradual decay and death, a dissolution. ... Necrobiosis is death brought on by (altered) life, a spontaneous wearing out of living parts, the destruction and annihilation consequent on life, natural as opposed to violent death (mortification).... But the idea of necrosis really does not offer any analogy to these processes. ..."

In summary, we should add to Virchow's accomplishments the early suggestion of apoptosis, which he called necrobiosis and which, he made very clear, was different from necrosis.

L. E. Gerschenson

University of Colorado Health Sciences Center

Denver, Colorado

$$
\text { F. Jon Geske }
$$

National Jewish Medical and Research Center

Denver, Colorado

\section{References}

1. Gerschenson LE, Rotello RJ: Apoptosis: a different type of cell death. FASEB J 1992, 6:2450-2455

2. Kerr JFR: A histochemical study of hypertrophy and ischaemic injury of rat liver with special reference to changes in lysosomes. J Pathol Bacteriol 1965, 90:419-435

3. Kerr JFR: Shrinkage necrosis: a distinct mode of cellular death J Pathol 1971, 105:13-20

4. Kerr JFR, Wyllie AH, Currie AR: Apoptosis: a basic biological phenomenon with wide-ranging implications in tissue kinetics. $\mathrm{Br} \mathrm{J}$ Cancer 1971, 26:239-257

5. Glucksman A: Cell deaths in normal vertebrate ontogeny. Biol Rev 1951, 26:59-86

6. Virchow R: Cellular Pathology. Translated by F Chance. New York, Dover Publications, 1971, p 358 